\title{
Europa, Química e Ambiente - Um Curso Tecnológico
}

\author{
DEPARTAMENTO DE CURSOS DE QUIMICA DA ESCOLA SECUNDÁRIA INFANTE D. HENRIQUE ${ }^{1}$
}

“20\% do volume de negócios europeus são facturados por 15 grandes complexos industriais químicos que fazem a imagem de marca da Europa, liderando este sector de actividades a nível mundial."

“Se o PIB da UE é baseado em mais de um terço na Indústria Química, não precisará de TÉCNICOS DE QUÍMICA ?"

I. Em relação ao Curso Tecnológico de Química (Química e Controlo Ambiental), programado para começar em 2004, levantam-se as seguintes questões:

- O país não precisará de Técnicos de Química?

Só nas 10 maiores empresas da Indústria Química há 6530 empregados, não incluindo outras Indústrias afins, tais como, Alimentar, Têxtil, Farmacêutica, Curtumes - Revista Pública de 11 de Novembro de 2002. Quantos destes não serão técnicos formados em Escolas Secundárias, nos cursos Tecnológicos e Técnico-profissionais?

- Porque não rentabilizar todo o enorme investimento já feito em Instalações, Equipamento e Formação/ Actualização de professores de Química?

O próprio DES continua a aplicar verbas nacionais e comunitárias em acções de formação de docentes.

- Como poderão as Escolas continuar a satisfazer os pedidos das empresas que solicitam técnicos desta área?

A Escola Secundária do Infante D. Henrique (Porto) forma técnicos de Química há mais de um século (desde 1897), para trabalhar nas áreas de Saúde, Química, Têxtil, Laboratórios Universitários, Institutos Estatais de Agricultura, Ambiente, Alimentação, Controlo e tratamento de Águas.

II. Em relação ao novo Curso de Ciências e Tecnologias do Agrupamento Científico-Humanístico, tal como os professores de Ciências da Escola Secundária Campos e Melo da Covilhã, questionamos:

- Como conciliar no $12^{\circ}$ ano a disciplina bienal ( $F e Q / B e G$ que são mais gerais) com outra mais específica?

Os conhecimentos previstos para as disciplinas mais especificas (Biologia, Geologia; Física e Química) requerem aprendizagens das matérias previstas das disciplinas de FQ e BG, que deveriam ter sido previamente aprendidas e não foram! E há uma complementaridade das duas áreas científicas (Física e Química/Biologia e Geologia) que foi tomada em consideração na elaboração dos novos programas.

\section{- Porque substituir disciplina(s) de Ciências Experimentais, com utiliza- ção, enquadrada num programa de conteúdo científico de reconhecido interesse, de meios informáticos por uma disciplina de Tecnologias de In- formação e Comunicação sem qual- quer enquadramento?}

É cada vez mais reconhecido por todos o papel primordial do ensino das ciências experimentais na sociedade actual e "que a formação científica dos cidadãos deve incluir três componentes, a saber: a educação em Ciência, a educação sobre Ciência e a educação pela Ciência.

"Segundo o documento da Reforma do Ensino Secundário "o desafio da escola do futuro está na capacidade de formar para a produção, tratamento e difusão de informação" o que será difícil com as TIC, uma vez que não se pode:

- produzir conhecimento científico sem trabalho experimental;

- tratar conhecimento que não se produziu;

- difundir conhecimento que não se adquiriu.".

III - Em Síntese Propomos

a) Inclusão do curso Tecnológico de Química e Controlo Ambiental ( com os programas homologados) no Agrupamento Tecnológico.

b) Que os cursos do Agrupamento Científico-Humanístico tenham 28,5 horas nos $10^{\circ}$ e $11^{\circ}$ anos, como os cursos do Agrupamento Tecnológico.

c) Que no $10^{\circ}$ ano TIC seja de 3 horas e passem a optar por duas disciplinas bianuais de 4,5 horas; e nos $11^{\circ} \mathrm{e}$ $12^{\circ}$ anos haja uma disciplina de Ciência Experimental de 3 horas em cada ano como oferta própria da Escola.

d) Que no $12^{\circ}$ ano os alunos optem por duas disciplinas anuais de 4,5 horas.

Porto, Dezembro de 2002/Fevereiro de 2003

\footnotetext{
${ }^{1}$ Os professores do $4^{\circ}$ Grupo B (grupo 16) da Escola Secundária do Infante D. Henrique (Porto).
} 